\title{
US turns blind eye to untested AIDS treatment drug imports
}

Washington \& Tokyo

US Food and Drug Administration commissioner Frank Young announced last week that the government would no longer try to stop the import of unapproved drugs for the personal treatment of AIDS

The decision will affect most strongly the import of dextran sulphate, a drug manufactured in Japan for the treatment of high blood-lipid levels and shown to hinder HIV virus binding in cell culture (see Nature 334, 3; 1988). The drug has become a popular self-treatment for AIDS patients in the United States. Imports by mail will now be permitted provided the amount is no more than a three-months' supply.

Young's announcement, made to a hostile audience at the National Lesbian and Gay Health Conference, represents a capitulation to the overwhelming pressure from people with AIDS to be allowed to try to treat themselves with drugs that are still untested. Only one drug, AZT, has received FDA approval for the treatment of AIDS and it has such powerul sideeffects that many AIDS patients have abandoned therapy with it.

Until last week's announcement, it appeared that the government was preparing to take a tougher line to restrict the availability of untested remedies. Earlier in the year, dextran sulphate, which is manufactured only in Japan, had been freely available from "buyers health clubs" in San Francisco, Los Angeles and New York and could be ordered by mail, even though it has not been tested for toxicity in the United States. But in April, in response to complaints from the United States, Japan began to make it harder for foreigners to buy the drug and export it.

Protests followed in the United States, including sit-ins by AIDS activists' groups in the Japanese consulate in San Francisco and the Manhattan office of Kowa, one of the biggest manufacturers of dextran sulphate.

The Japanese Ministry of Health and Welfare will now allow three pharmacies -two close to Tokyo's international airport at Narita, and one, the American Pharmacy, close to the Ginza shopping district - to sell the drug to foreigners for export. A spokeswoman at the American pharmacy said that they would sell a maximum of $10,000300-\mathrm{mg}$ tablets to any one individual. The purchaser must show a passport and sign a form recognizing the drug has no proven effect against AIDS.

Free availability of dextran sulphate may make it harder to test new therapies against AIDS. Many doctors running clinical trials report that their patients were taking unknown quantities of other untested drugs. In tests of $\mathrm{AZT}$, some patients took their medicine to independent laboratories for analysis; those who found they had been given a placebo dropped out of the trials, making assessment of the treatment more difficult. Interpretation of phase I toxicity tests of dextran sulphate were also complicated when patients boosted their hospital doses with dextran sulphate bought from health clubs.

A spokesman at the San Francisco
General Hospital, where dextran sulphate has been under test, stressed that patients involved in clinical trials "had to be a little altruistically motivated", "trust their doctors" and recognize "that they would do themselves and other people with AIDS a disservice by taking untested drugs". But people-with-AIDS groups say that trust has been hard to give when it appears that the government is not testing and licensing new drugs quickly enough and is insensitive to the need of those dying from AIDS to try anything that might help.

The new official policy on untested therapies may help to restore faith in the FDA's good intentions.

Alun Anderson \& David Swinbanks

\section{House of Representatives due to decide on animal patents}

Washington

THE US House of Representatives Committee on the Judiciary will this week consider two drastically different ways to resolve the complex ethical, procedural and economic issues surrounding the patenting of animals. The committee will decide whether Congress should establish a two-year moratorium on the granting of patents covering animals, or allow the patenting of animals to continue, but exempt researchers and farmers from paying royalty fees after breeding the animals.

Congress became obliged to set policy over the patenting of animals after the US Patent and Trademark Office decided in April of last year to accept applications for animal patents. The patent office ruled that it could no longer stand in the way of patenting animals simply because they were higher life forms (Nature 326, 729; 1987). During the public furore that then erupted, the patent office made clear that its hands were tied by the judicial interpretation of current patent laws, and that it was up to Congress to weigh the implications and set down new laws if the policy was unacceptable.

For the past year, animal rights activists, religious leaders, farming organizations and anti-biotechnology agitator Jeremy Rifkin have formed unlikely alliances to lobby Congress to assess the patent office's new policy. Senator Mark Hatfield (Republican, Oregon) and Representative Charles Rose (Democrat, North Carolina) both entered legislation last year to suspend the granting of patents on animals until the surrounding issues could be evaluated.

But while Congress has been in a flurry of activity to come to grips with the technology to create "new" animals, the patent office has continued to process the roughly 20 applications it has on hand. It granted a patent to Harvard University in April when all of the legal hurdles to patentability were jumped by " $m y c-y$ mouse" - a mouse made susceptible to the development of cancer by the insertion of the myc oncogene into its genome (Nature 332, 668; 1988).

Congress this week is reconsidering Representative Rose's bill calling for a two-year moratorium on the patenting of animals, along with a more moderate bill entered by Representative Robert Kastenmeier (Democrat, Wisconsin) which would exempt researchers and farmers from the royalty payments required under normal patent law for the use of patented animals. No action has yet been taken on a stricter bill proposing an indefinite moratorium on animal patenting which has been entered again this year in the Senate by Senator Hatfield.

Representative Kastenmeier has also sponsored a bill to establish a transgenic animal advisory committee in the Department of Agriculture to oversee the environmental release of genetically engineered animals eligible for patenting.

Critics of the patenting of animals state that it equates "cows with toasters", and that it will lead to higher prices for farm and laboratory animals and reduce the genetic diversity of animals important to US agriculture. Proponents claim that it encourages innovation, and contend that the patenting of plant varieties - permitted since 1970 - has not been the cause of a recent escalation in seed prices.

But some are not prepared to wait for Congress to resolve these issues: the Animal Legal Defense Fund, an animal rights organization, last week filed suit against the US patent office accusing it of violating the Patent Act, and the laws governing the establishment of new policies by Federal agencies, by granting animal patents.

Carol Ezzell 